\title{
INTERCROPPING OF SPINACH WITH BOTTLEGOURD AS A LEAFY VEGETABLES UNDER DIFFERENT PLANTING METHODS
}

\author{
M.S. Islam ${ }^{1}$, M.F. Khatun ${ }^{2 *}$, Q. Naher ${ }^{3}$, M.F. Hossain ${ }^{3}$, M.S. Hossain ${ }^{4}$ \\ ${ }^{1}$ SSO, OFRD, BARI, Kishoreganj-2300; ${ }^{2}$ SSO, PGRC, BARI, Gazipur-1701; ${ }^{3}$ SSO, OFRD, BARI, Gazipur-1701; ${ }^{4}$ SSO, \\ SRDI, Regional Laboratory, Kishoreganj-2300 \\ *Corresponding Email: mfkhatun79@gmail.com
}

(Received: 25 September 2021, Accepted: 15 December 2021)

Keywords: Intercropping, leafy vegetables, spinach, bottle gourd, land equivalent yield

\begin{abstract}
Intercropping is the option of growing more crops in the same piece of land for additional profit and to mitigate the losses or failure of the main crop. Considering this view, an experiment was designed to observe the growth and yield performance of spinach as an intercrop with bottle gourd as leafy vegetable under various planting method to increase productivity and economic return. The study included four planting systems viz; broadcasting spinach with bottle gourd, line sowing spinach with bottle gourd, sole bottle gourd and sole spinach followed by RCB design with three dispersed replications. Based on the growth and yield performance with economic return, intercropping performed better than sole cropping. The higher bottle gourd equivalent yield (15.67 to $28.36 \%)$ was obtained in line sowing of spinach with bottle gourd than sole bottle gourd. The land equivalent ratio (LER) showed a positive influence on intercropping systems compare to monoculture. The maximum gross return (Tk. $430000 \mathrm{ha}^{-1}$ ), gross margin (Tk. $325000 \mathrm{ha}^{-1}$ ) and BCR (4.10) was obtained from line sowing of spinach with bottle gourd. This practice could be able for better return with the same input and using the same area of land with minimum risk.
\end{abstract}

\section{Introduction}

In Bangladesh, the majority of farmers are practicing monoculture rather than an intercropping system. However, intercropping use nutrients efficiently and gives greater yield stability over monoculture (Seran and Brintha, 2010). Moreover, mixed or intercropping can ensure maximum land utilization of the available resources and compared with each sole crop to increase productivity (Launay et al., 2009;Mucheru-Muna et al., 2010). In the past, bottle gourd was consumed as Lau but recently the young leaves and twigs as shak are getting popularity due to its palatability and health benefits. At present, laushak production areas are covering 16156 acres of land with total production of 26812 metric tons (BBS, 2019). Farmers can harvest twig at least 8-10 times within a season from a single plant. But nowadays, the price of 3-4 twigs of laushak remains expensive and varies Tk. 15-20 in the local market. After 7-10 days of twig cutting, another 3 to 4 twigs comes out from each plant and grow up quickly due to epical dominance. On the other hand, spinach as a short duration vegetable it can quickly grow up in the line without causing yield hamper. In the early season, the price of spinach also expensive in market compare to other vegetables. Therefore, farmers can get spinach within a short time as an additional cropand canearn extraearly income. Hence, this study has been conducted to observe the growth and yield performance of spinach as an intercrop with bottle gourd.

\section{Material and method}


The experiment was conducted at MLT site Hossainpur (AEZ -7, Latitude $24^{\circ} 25^{\prime} \mathrm{N}$ and longitude $90^{\circ}$ $39^{\prime}$ E) under OFRD, BARI, Kishoreganj during the rabi season of 2015-16 and 2016-17 to evaluate the performance of intercropping spinach with bottle gourd as a leafy vegetable. Four planting systems were maintained $\mathrm{T}_{1}$ : broadcasting spinach with bottle gourd, $\mathrm{T}_{2}$ : line sowing spinach with bottle gourd, $\mathrm{T}_{3}$ : Sole Bottle gourd and $\mathrm{T}_{4}$ : Sole spinach. The completely randomized block design with three dispersed replications was laid out. Seeds sowing was done on 5 October 2015 and 24 October 2016. Bottle gourd was planted 50 and $25 \mathrm{~cm}$ of line to line and plant to plant distances, respectively where 15 and $10 \mathrm{~cm}$ for spinach. Fertilizer doses: $\mathrm{N}_{75} \mathrm{P}_{25} \mathrm{~K}_{60} \mathrm{~kg}$ and 10 tons per hectare decomposed cowdung were used. Full dose cowdung, TSP and 1/2 amount of MoP were applied at final land preparation. One-third urea was applied at 21 DAS after seed sowing. The rest of urea and MoP were applied at the time of each cutting of bottle gourd twig. Irrigation and intercultural operations were done as and when necessary. Foliar application of liquid fertilizer at 10 days interval was also done three times to enhance the vegetative growth. Secure was also used 3 times to protect the gummosis disease on the same day's interval. The insecticide Confidor and Desis were also used 2 times in the growing season to control red pumpkin beetle and aphid. Fifteen-time twig of bottle gourd was harvested as a leafy vegetable from single plant whereas spinach was harvested on 18 November 2015 and Lau shak started from 25 November 2015 in 2015-16 cropping season. In 2016-17, spinach was harvested on 30 November 2016 and Lau shak on 5 January 2017. As an intercrop, the spinach yield was converted to equivalent laushak yield. Data recorded on yield and yield attributing characters and analyzed the mean differences by (LSD) test (Gomez and Gomez, 1984). The laushak equivalent yield ( $\mathrm{t} \mathrm{ha} \mathrm{H}^{-1}$ ) was quantified by using the equation (1) mentioned by Prasad and Srivastava (1991). On the other hand, the land equivalent ratio was also calculated by equation (2) (Mian, 2008). Moreover, based on the prevailing market price of bottle gourd and spinach was considered to calculate the economic performance following the existing market price.

$$
\begin{aligned}
& \text { BEY }\left(\mathrm{t} \mathrm{ha}^{-1}\right)=\text { Bottle gourd yield }\left(\mathrm{t} \mathrm{ha}^{-1}\right)+\frac{\text { Spinach yield }\left(\mathrm{tha}^{-1}\right) \times \text { Spinach price }\left(\mathrm{Tk} . \mathrm{kg}^{-1}\right)}{\text { Bottle gourd price }\left(\mathrm{Tk}_{\mathrm{kg}} \mathrm{kg}^{-1}\right)} \ldots(1) \\
& \text { LER }=\frac{\text { Yield of intercrop(Bottle gourd) }}{\text { Yield of sole crop (Bottle gourd) }}+\frac{\text { Yield of intercrop (Spinach) }}{\text { Yield of sole crop (Spinach) }}
\end{aligned}
$$

Table 1. Nutrient status of cowdung (\%)

\begin{tabular}{ccccccccccc}
\hline $\begin{array}{c}\text { Name of the } \\
\text { manure }\end{array}$ & $\mathbf{p H}$ & $\mathbf{O M}$ & $\mathbf{C a}$ & $\mathbf{M g}$ & $\mathbf{K}$ & Total N & $\mathbf{P}$ & $\mathbf{S}$ & $\mathbf{B}$ & $\mathbf{Z n}$ \\
\hline Cowdung & 7.2 & 8.5 & 1.74 & 0.53 & 0.56 & 0.57 & 0.8 & 0.2 & 0.012 & 0.14 \\
\hline
\end{tabular}

The initial soil samples of the experimental field were collected and analyzed (Table 2). The $\mathrm{pH}, \mathrm{OC}$ and total nitrogen of the soil were highly acidic (5.51), low (0.91\%) and low (0.06\%), respectively, while available $\mathrm{P}, \mathrm{K}, \mathrm{Ca}, \mathrm{Mg}, \mathrm{S}, \mathrm{Zn}$ and $\mathrm{B}$ were over the critical value.

\begin{tabular}{|c|c|c|c|c|c|c|c|c|c|c|}
\hline \multirow[t]{2}{*}{ Soil depth } & \multirow[t]{2}{*}{ pH } & \multirow{2}{*}{$\begin{array}{l}\mathrm{OC} \\
(\%)\end{array}$} & \multirow{2}{*}{$\begin{array}{c}\text { Total N } \\
(\%)\end{array}$} & \multirow{2}{*}{$\begin{array}{c}\mathbf{P} \\
\left(\mathrm{mg} \mathrm{kg}^{-1}\right)\end{array}$} & $\mathbf{K}$ & $\mathbf{C a}$ & Mg & $\mathbf{S}$ & $\mathbf{Z n}$ & B \\
\hline & & & & & \multicolumn{3}{|c|}{$\left(\mathrm{mg} 100 \mathrm{~g}^{-1}\right)$} & \multicolumn{2}{|c|}{$\mathrm{mg} \mathrm{kg}^{-1}$} & \\
\hline $0-20(\mathrm{~cm})$ & 5.51 & 0.91 & 0.06 & 20 & 0.19 & 3.8 & 1.6 & 10.5 & 2.13 & 0.61 \\
\hline Critical level & - & - & - & 7.0 & 0.12 & 2.0 & 0.5 & 10 & 0.60 & 0.20 \\
\hline
\end{tabular}

Table 2. Chemical properties of initial soil sample in the study field

The average maximum precipitation of $25.7 \mathrm{~mm}$ in October and the minimum rainfall $8.2 \mathrm{~mm}$ recorded in January. Besides, the average maximum temperature was $31.96^{\circ} \mathrm{C}$ in the month of October and $12.95^{\circ} \mathrm{C}$ as minimum temperature in January.

\section{Results and Discussion}

Yield and yield contributing characters of bottle gourd 
The yield and yield contributing characters of bottle gourd as leafy vegetable were influenced significantly under different planting system with spinach except number of twigs per plant (Table 4). The maximum average twig length $\left(87.26 \mathrm{~cm}\right.$ ) was recorded from $T_{3}$ treatment (sole bottle gourd) which was $(78 \mathrm{~cm})$ statistically similar to $T_{2}$ treatment (line sowing spinach with bottle gourd) may be due to minimum interspecific competition as well as optimum light interception, nutrient and water uptake for growth that reflects on higher twig length. The lowest average twig length $(71.85 \mathrm{~cm})$ was found in $\mathrm{T}_{1}$ treatment. A Similar trend was found in individual twig weight $(\mathrm{g})$ and bottle gourd twig yield $\left(\mathrm{t} \mathrm{ha}^{-1}\right)$. The highest average individual twig weight was obtained $(89.6 \mathrm{~g})$ in $\mathrm{T}_{3}$ treatment (sole bottle gourd) and the lowest was obtained $(155.8 \mathrm{~g})$ from $\mathrm{T}_{1}$ treatment which was statically at par to $\mathrm{T}_{2}$ treatment. The maximum average bottle gourd twig yield $\left(13.33 \mathrm{t} \mathrm{ha}^{-1}\right)$ resulted in $\mathrm{T}_{3}$ treatment (Sole bottle gourd) that was statically similar $\mathrm{T}_{2}$ treatment $\left(12.06 \mathrm{t} \mathrm{ha}^{-1}\right)$. The similar result was reported by Bhuiyan et al. (1999); OFRD (2006) where intercropping provided the highest yield than sole maize. The minimum bottle gourd twig yield was found $\left(11.40 \mathrm{t} \mathrm{ha}^{-1}\right)$ in $\mathrm{T}_{1}$ treatment (broadcasting spinach with bottle gourd).

Table 4. Performance of yield and yield contributing characters of bottle gourd as leafy vegetables at different planting system during 2015-16 and 2016-17

\begin{tabular}{|c|c|c|c|c|c|c|c|c|c|}
\hline \multirow[t]{2}{*}{ Treatments } & \multicolumn{2}{|c|}{$\begin{array}{l}\text { Twig length } \\
\text { (cm) }\end{array}$} & \multirow[t]{2}{*}{ Mean } & \multicolumn{2}{|c|}{$\begin{array}{c}\text { Individual } \\
\text { Twig weight (g) }\end{array}$} & \multirow[t]{2}{*}{ Mean } & \multicolumn{2}{|c|}{$\begin{array}{l}\text { Bottle gourd } \\
\text { twig yield }\left(\mathrm{t} \mathrm{ha}^{-1}\right)\end{array}$} & \multirow[t]{2}{*}{ Mean } \\
\hline & $2015-16$ & 2016-17 & & $2015-16$ & 2016-17 & & 2015-16 & $2018-17$ & \\
\hline $\mathrm{T}_{1}$ & 73.40 & 70.30 & 71.85 & 151.6 & 160 & 155.8 & 11.22 & 11.57 & 11.40 \\
\hline $\mathrm{T}_{2}$ & 76.00 & 80.00 & 78.00 & 162.0 & 173.3 & 167.7 & 11.89 & 12.23 & 12.06 \\
\hline $\mathrm{T}_{3}$ & 86.40 & 88.52 & 87.46 & 194.0 & 185.2 & 189.6 & 13.25 & 13.41 & 13.33 \\
\hline $\operatorname{LSD}(0.05)$ & 10.6 & 9.22 & - & 10.63 & 12.12 & - & 0.78 & 1.42 & - \\
\hline CV (\%) & 5.86 & 6.12 & - & 17.12 & 11.55 & - & 6.57 & 4.89 & - \\
\hline
\end{tabular}

LSD=Least significant differences, $\mathrm{NS}=$ No significant, $\mathrm{CV}=$ Coefficient of variance, , $\mathrm{T}_{1}$ : Broadcasting, spinach with bottle gourd, $\mathrm{T}_{2}$ : line sowing spinach with bottle gourd, $\mathrm{T}_{3}$ : sole bottle gourd

\section{Spinach yield as intercrop}

The average, yield data has been presented in table 5. The maximum spinach yield was recorded $(4.44 \mathrm{t}$ $\mathrm{ha}^{-1}$ ) from $\mathrm{T}_{4}$ Treatment (sole spinach) which was statistically similar in $\mathrm{T}_{2}$ treatment $\left(3.83 \mathrm{tha}^{-1}\right)$ it might be less sharing of input. Quayyum and Maniruzzaman(1995) who reported that the single cropping practice having little or no sharing of input sun and air within the plants. On the contrary, the minimum spinach yield was obtained $\left(3.29 \mathrm{tha}^{-1}\right)$ in $\mathrm{T}_{1}$ treatment.

\section{Bottle gourd equivalent yield}

The equivalent yield of bottle gourd was influenced by different cropping systems (Table 5). The highest bottle gourd equivalent yield was found $\left(17.2 \mathrm{t} \mathrm{ha}^{-1}\right)$ in $\mathrm{T}_{2}$ treatment than the sole spinach and the sole bottle gourd due to adding intercrop yield. Total productivity can increase significantly as compared to single cropping by making better use of water, nutrients and solar energy (Yildirim and Guvenc, 2005). Alom et al. (2013) also reported the brinjal equivalent yields (BEY) in all intercropping systems were found higher than sole brinjal indicating higher productivity of intercropping systems. Similar results were also reported by Suresha et al. (2007) in different chilli based intercropping systems. $T_{1}$ treatment gave the second highest equivalent yield $\left(15.5 \mathrm{t} \mathrm{ha}^{-1}\right)$ which was statistically similar to $\mathrm{T}_{3}$ due to higher bottle gourd twig weight. On the other hand, the lowest bottle gourd equivalent yield was found in $\mathrm{T}_{4}$ treatment $\left(4.44 \mathrm{t} \mathrm{ha}^{-1}\right)$. By practicing this system yield increased over the sole bottle gourd 15.67 to $28.36 \%$ from the intercropping treatments.

\section{Land equivalent ratio}


The maximum LER value was calculated from $\mathrm{T}_{2}$ treatment (1.80) followed by $\mathrm{T}_{1}$ treatment (1.60)(Table $5)$ which was indicated the superiority of intercropping over both sole crop $\left(\mathrm{T}_{3}\right.$ and $\left.\mathrm{T}_{4}\right)$.

Table 5. Equivalent yield and percent yield (\%) increased of bottle gourd and spinach during 2015-16 and 2016-17 (Average)

\begin{tabular}{|c|c|c|c|c|c|c|}
\hline \multirow[t]{2}{*}{ Treatments } & \multicolumn{2}{|c|}{$\begin{array}{c}\text { Spinach yield } \\
\left(\mathrm{t} \mathrm{ha}^{-1}\right)\end{array}$} & \multirow{2}{*}{$\begin{array}{l}\text { Spinach } \\
\text { yield } \\
\left(\mathrm{t} \mathrm{ha}^{-1}\right)\end{array}$} & \multirow{2}{*}{$\begin{array}{l}\text { Bottle gourd } \\
\text { twig yield } \\
\left(\mathrm{t} \mathrm{ha}^{-1}\right)\end{array}$} & \multirow{2}{*}{$\begin{array}{l}\text { Bottle gourd } \\
\text { equivalent yield } \\
\left(\mathrm{t} \mathrm{ha}^{-1}\right)\end{array}$} & \multirow[t]{2}{*}{ LER } \\
\hline & $2015-16$ & $2016-17$ & & & & \\
\hline $\mathrm{T}_{1}$ & 3.09 & 3.48 & 3.29 & 11.4 & 15.5 & 1.60 \\
\hline $\mathrm{T}_{2}$ & 3.56 & 4.10 & 3.83 & 12.6 & 17.2 & 1.80 \\
\hline $\mathrm{T}_{3}$ & - & - & - & 13.4 & 13.4 & 1.00 \\
\hline $\mathrm{T}_{4}$ & 4.12 & 4.76 & 4.44 & - & 4.44 & 1.00 \\
\hline
\end{tabular}

$\mathrm{T}_{1}$ : Broadcasting spinach with bottle gourd, $\mathrm{T}_{2}$ : line sowing spinach with bottle gourd, $\mathrm{T}_{3}$ : sole bottle gourd andT $\mathrm{T}_{4}$ : sole spinach

LER: Land equivalent ratio

\section{Economic performance of spinach with bottle gourd as a leafy vegetable}

Intercropping system spinach with bottle gourd economically profitable than sole cropping (Table 6). The highest gross return (Tk. $430000 \mathrm{ha}^{-1}$ ), gross margin (Tk. $105000 \mathrm{ha}^{-1}$ ) as well as BCR (4.10) were recorded in $\mathrm{T}_{2}$ treatment. Uddin et al., 2009 also reported that maize + spinach provided the highest yield with highest gross income followed by maize + lalshak and maize + potato, but sole crop maize had produced lowest yield with a least gross return. In the case of the intercropping system, the total variable cost was high due to cultivation cost was much higher under all intercropping systems than sole cropping because of extra labor cost for sowing, harvesting and intercultural activities for the two crops cultivation.

Table 6. Equivalent yield and economic analysis ofspinach with bottle gourd intercropping at different planting system

\begin{tabular}{|c|c|c|c|c|c|c|}
\hline Treatments & $\begin{array}{c}\text { Bottle gourd } \\
\text { equivalent yield } \\
\left(t \text { ha }^{-1}\right)\end{array}$ & $\begin{array}{c}\text { Yield increased } \\
\text { over sole } \\
\text { Bottle gourd }(\%)\end{array}$ & $\begin{array}{l}\text { Gross return } \\
\quad\left(\mathbf{T k} . \mathbf{h a}^{-1}\right)\end{array}$ & $\begin{array}{r}\text { Total Cost } \\
\left(\text { Tk. ha' } \mathbf{h}^{-1}\right)\end{array}$ & $\begin{array}{c}\text { Gross } \\
\text { margin } \\
(\text { Tk. ha-1) }\end{array}$ & BCR \\
\hline $\mathrm{T}_{1}$ & 15.5 & 15.67 & 384500 & 102000 & 282500 & 3.77 \\
\hline $\mathrm{T}_{2}$ & 17.2 & 28.36 & 430000 & 105000 & 325000 & 4.10 \\
\hline $\mathrm{T}_{3}$ & 13.4 & - & 335000 & 98000 & 237000 & 3.42 \\
\hline $\mathrm{T}_{4}$ & 4.44 & - & 111000 & 80000 & 31000 & 1.40 \\
\hline
\end{tabular}

$\mathrm{T}_{1}$ : Broadcasting spinach with bottle gourd, $\mathrm{T}_{2}$ : line sowing spinach with bottle gourd, $\mathrm{T}_{3}$ : sole bottle gourd and $\mathrm{T}_{4}$ : sole spinach,

TVC: Total Variable Cost, BCR: Benefit Cost Ratio,

Price: Bottle gourd twig (Lau shak) Tk.25 kg-1 and spinach Tk.30 kg-1

The intercropping system gave higher gross margin than the sole cropas reported by Razzaque et al. (2007) \&Alom et al. (2008). In this study, the highest gross return (Tk.111000 ha-1), gross margin $\left(\right.$ Tk.8000 ha-1) from $\mathrm{T}_{4}$ treatment but BCR much lower (1.40) so, treatment $\mathrm{T}_{2}$ showed higher BCR (4.10) followed by $\mathrm{T}_{3}$ (3.42) due to higher gross return.

\section{Conclusion}

Vegetable cultivation under the intercropping system is more profitable and viable in terms of economically and agronomical aspects which able to increase the total production. The study revealed that the intercrop of spinach or any short duration vegetables especially line sowing with bottle gourd would be suitable and profitable for in Bangladesh. Farmers are interested to cultivate leafy vegetable with bottle gourd which would contribute some additional profit with minimum effort and costing, thereby met up the vegetable requirement and nutritional demand of the farm family. 


\section{Acknowledgements}

The authors thank the owner of the experimental field for providing land and continuous support to conduct the research. The authors also express their gratitude to thescientific assistant who involves this study and acknowledge to the MoA and BARI, Gazipur for ensuring financial support to carry out the research.

\section{References}

Alom, M.S., N.K. Paul and M.A. Quayyum. 2008. Performance of hybrid maize (Zea mays L.) under intercropping systems with mungbean (Vigna radiata L.) in different planting methods. SAARC J. Agri. 6(2): 73-82.

Alom, M.S., B.L. Nag, M.N. Islam, F.Ahmed and S.Akther. 2013. Performance of different crop species with pointed gourd (Trichosanthes dioica Roxb.) Bangladesh J. Agril. Res. 38(3): 523-529.

Akhtar, S., M.S. Zaman, N. Sultana, M.A.H. Khan, M.M. Zaman, S. Sultana and M.K. Alam. 2015. Intercropping of short duration vegetables with hybrid maize. Int. J. Appl. Res. 1(2): 113-116.

BBS (Bangladesh Bureau of Statistics). 2019. Agricultural Statistical Yearbook of Bangladesh. Statistics Division, Bangladesh Bureau of Statistics. Ministry of Planning, Government of the People's Republic of Bangladesh, Dhaka.

Bhuiyan, M.K.A., M.M. Haque, Q.A.Khaliq, J.A. Begum and A.H.M.R. Mawlla. 1999. Productivity and economics of grain legumes intercropped with maize. Bangladesh Agron. J. 9 (1\&2): 35-42.

Black, C.A. 1965. Method of soil analysis Part -I and II. Am. Soc. Agronomy Inc. Madison, Wiscosin, USA. p.770.

Caballero R., E.L. Goicoechea and P.J. Hernaiz.1995. Forage yield and quality common vetch and oat sown at varying seed ratios and seedling rates of common vetch. Field Crops Res. 41: 135-140.

Farhad, I.S.M., M.M.U. Chowdhury, S.K. Bhowal, A.K. Choudhury and A.S.M.M.R. Khan. 2014. Chilli-Garlic intercropping system in costal saline area. App. Sci. Report. 6(2): 47-50.

Gomez, K.A. and A.A. Gomez. 1984. Statistical Procedures for Agricultural Research (2nd ed.). NewYork: Wiley. pp.188-206.

Hanlon, E.A. and G.V. Johnson. 1984. Bray/Kurtz, Mehlich ill, AB/D and Ammonium Acetate Extraction of P, K, and Mg in Four Oklahoma Soils. Commun. Soil Sci. Plant Anal.15: 277-294.

Islam, M.S., M.F. Khatun, A.S.M.M.R. Khan, S. Istiaque and M.F. Hossain. 2016. Intercropping vegetables with maize in the haor Area of Kishoreganj. J. Agril. Sci. 1(2): 49-53.

Islam, M.R., M.A.K. Main, N. Ara and M.F. Hossain. 2013. Intercropping lentil and turmeric relayed with pointed gourd. Bangladesh J. Agric. Environ. 9(1): 33-37.

Islam, M.N., M. Akhteruzzaman, M.S. Alom and M. Salim. 2014.Hybrid maize and sweet potato intercropping: A technology to increase productivity and profitability for poor hill farmers in Bangladesh. SAARC J. Agri. 12(2): 101-111.

Jackson, M.L. 1962. Soil Chemical Analysis. New York: Prentice-Hall Inc. p.498.

Karim, Z., S.M. Rahman, M.I. Ali and A.J.M.S. Karim. 1988. Soil bulk density: A manual for determination of soil physical parameters. Dhaka, Bangladesh: Soils and Irrigation Division, BARC.

Launay, M., N. Brisson, S. Satger, H. Hauggaard-Nielsen, G. Corre-Hellou, E. Kasynova, R. Ruske, E.S. Jensen and M.J. Gooding. 2009. Exploring options for managing strategies for pea-barley intercropping using a modeling approach. Eur. J. Agron. 31: 85-98.

Mucheru-Muna, M., P. Pypers, D. Mugendi and B. Vanlauwe. 2010. A staggered maize-legume intercrop arrangement robustly increases crop yields and economic returns in the highlands of Central Kenya. Field Crops Res. 115: 132-139. 
Mian, M.A.K. 2008. Performance of maize oriented cropping patterns under different nutrient management. Ph. D. Dissertation. Dept. Agron. Bangladesh Agril. Univ., Mymensingh. pp. 31-137.

Matusso, J.M.M., J.N. Mugwe, and M. Mucheru-Muna. 2012. Potential role of cereal-legume intercropping systems in integrated soil fertility management in smallholder farming systems of sub-Saharan Africa Research Application Summary. Third RUFORUM Biennial Meeting 24-28 September 2012, Entebbe, Uganda.

Okigbo, B.N. 1979. Evaluation for plant interactions and productivity in complex mixtures as a basis for improved cropping systems design: In: Proc. Intl. Workshop on intercropping 10-13 Jan., Hyderbad, India.pp.350-356.

OFRD (On-Farm Research Division).2006. Bangladesh Agricultural Research Institute, Joydebpur, Gazipur, Intercropping maize with short duration vegetables crop. Annual Res. Report. pp.291-297.

Prasad, K. and V.C. Srivastava. 1991. Pigeonpea (Cajanus cajan) and soybean (Glycine max) intercropping system under rainfed situation. Indian J. Agric. Sci. 61(4): 243-246.

Quayyum, M.A. and A.F.M. Maniruzzaman. 1995. Effect of maize (Zea mays L.) and rice (Oryza sativa) with black gram (Phaseolus mungo). Indian J. Agron. 40(1): 20-25.

Rodge, B.M. and S.S. Yadlod. 2009. Studies of intercropping in vegetables. Intl. J. Agril. Sci. 5(2):357-358.

Razzaque, M.A., S. Rafiquzzaman, M.M.M. Bazzaz, A. Ali and M.M.R. Talukdar. 2007. Study on the intercropping groundnut with chilli at different plant populations. Bangladesh J. Agril. Res. 32(1): $37-43$.

Seran, T.H. and I. Brintha. 2010. Review on Maize based intercropping. J. Agron. 9(3): 135-145.

Saddam, A.A. 2009. Effect of intercropping of Zeamaize with potato Solanum tuberosum, L. on potato growth and on the productivity and land equivalent ratio of potato and maize. J. Agric. 4: 164-170.

Suresha, B.A., T.B. Allolli, M.G. Patil, B.K. Desai and S.A Hussain. 2007. Yield and Economics of Chilli Based Intercropping System. Karnataka J. Agric. Sci. 20 (4): 807-809.

Sperber, I. 1948. A Direct Turbidimetric Method for Determining Eitheral Sulfates in Urine. J. Bio. Chem. 172: 441-444.

Uddin, M.J., M.A. Quayyum and K.M. Salahuddin. 2009. Intercropping of hybrid maize with short duration vegetables at hill valleys of Bandarban. Bangladesh J. Agric. Res. 34(1): 51-57.

Van Oort, P.A.J., F.Gou, T.J. Stomphand van der Werf, W. 2020. Effects of strip width on yields in relay-strip intercropping: A simulation study. European J.Agron.112:125936.

Walkley, A. and I.A. Black. 1934. An examination of Degtjareff method for determining soil organic matter and a proposed modification of the chromic acid titration method. Soil Sci. 37: 29-37.

Yildirim, E. and I. Guvenc. 2005. Intercropping Based on Cauliflower: More Productive, Profitable and Highly Sustainable. European J. Agro. 22: 11-18. 